\title{
Hazard identification process in the selected analysis domain of the F100 turbofan engines maintenance system
}

The multirole F-16 is the most advanced aircraft in the Polish Air Forces. It has been equipped with the very modern, sophisticated and advanced turbofan engine F100-PW-229. Due to the fact, that there is only one engine, its reliability, durability efficiency and performance are the crucial factors for the safety reasons. In the article authors researched maintenance system of the F100 turbofan engines, which are built on the multirole F-16 aircraft. For the study purposes F100 maintenance system model has been created. From this model, the main analysis domain was derived, comprising "Major engine objects discrepancies removal" process. Considering such an analysis domain, on the basis of the schematic diagram of the hazard identification process, authors presented the following procedures: tools preparation for the hazard sources identification, hazard sources identification, hazard sources grouping and hazards formulation. The main goal of this article was to provide hazard identification process results as hazard specifications, which include: a group of hazard sources, hazards formulation and the most probable/predictable consequences, severities and losses/harms of the hazard activation.

Key words: hazard source, hazard, hazard identification, risk management, F100 turbofan engine, maintenance system

\section{Introduction}

The F-16C/D Block 52 is powered by the Pratt \& Whitney F100-PW-229 low-bypass, high compression ratio, fully ducted, twin-spool turbofan engine with an annular combustor and a mixed flow augmentor.

The F100-PW-229 engine general specifications are:

- Thrust

- Maximum rating (augmented operation) $=29,100$ lbs. $(129.4 \mathrm{kN})$

- Intermediate rating (non-augmented operation) = 17,800 lbs. $(79.2 \mathrm{kN})$

- Weight

- F-15; 3,784 lbs. (1,716 kg)

- F-16; 3,819 lbs. $(1,732 \mathrm{~kg})$

- Length

- 208 in. (5.28 m)

- Diameter

- Inlet diameter $=34.8 \mathrm{in} .(0.88 \mathrm{~m})$

- Maximum diameter $=46.5$ in. $(1.18 \mathrm{~m})$

- Bypass ratio $=0.36: 1$

- Overall pressure ratio $=32: 1$

The engine is also equipped with a full length annular duct and a variable convergent/divergent exhaust nozzle. It also incorporates variable vanes at the inlet of both compressors and a variable exhaust nozzle. The major rotating sections are supported by five main bearings.

The F100-PW-229 engine is designed to maximize its performance. Some features are:

- High thrust to weight ratio

- $29,100 \mathrm{lbs} . / 3,800 \mathrm{lbs} .=7.7: 1$

- Variable vanes

- Compressor inlet variable vanes (CIVV)

- Rear compressor variable vanes (RCVV)

- Fully ducted engine

- Mixed flow augmentor

- Mixes core air flow with bypass air flow

- Variable exhaust nozzle

The engine is constructed using the modular concept, allowing the removal of functionally and physically associated parts as units, called modules.
The modular concept helps increase maintainability by:

- Allows removal of parts as units (modules).

- Allows replacement of unserviceable modules with serviceable modules.

- Allows rapid return of the engine and modules to service.

The modular concept does not prevent replacement of subassemblies or parts when replacement is the most effective repair method. Designed with the modular concept, the engine consists of the five modules (Fig. 1):

1. Inlet fan module

2. Core engine module

3. Fan drive turbine module

4. Augmentor duct and nozzle module

5. Gearbox module.

\section{Engine maintenance system model as an aggre- gated analysis domain}

The purpose of the engine maintenance system is to assess the F100-PW-229 engines powering the PLAF F-16 aircraft for serviceability and safety of flight.

The F100 family of engines has been designed to be maintained using three levels of maintenance explained in this section. Engine maintenance system is based on Modular Maintenance Concept.

F100 engine comprises of five major modules:

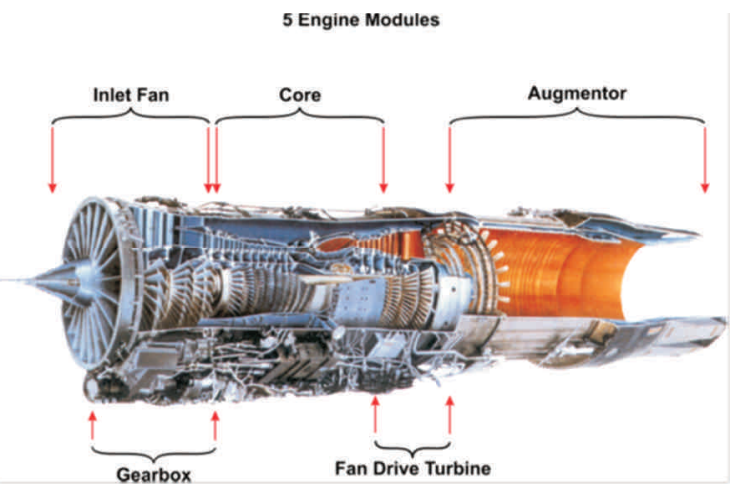

Fig. 1. F100 engine design structure [1] 
The whole maintenance concept is organized in the way, which is based on the main idea that $97 \%$ of nonoverhaul maintenance should be completed at the base Fig. 2.

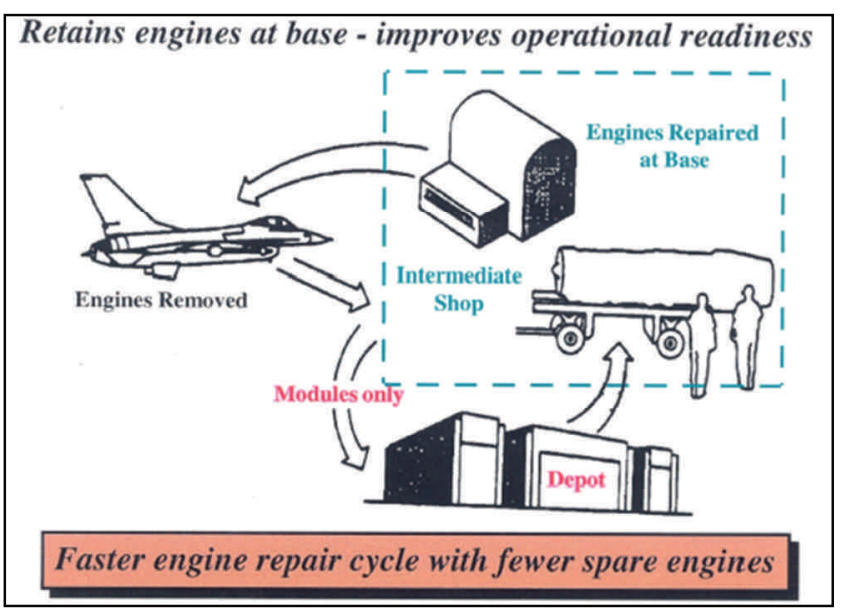

Fig. 2. Engine maintenance concept model

The main reason for such an arrangement is to keep as many engines and engine modules, as well as engine LRUs (Line replaceable units) on base, available for the fast discrepancy removal. Immediate removal and replacement of the engine broken object is the key element for the engine operational readiness and aircraft mission capability rate. To summarize, we are able to distinguish three different engine maintenance levels (Fig. 3).

I. Organizational (O) - Level, Flightline Maintenance Maintenance repairs and inspections with engine installed in aircraft:

- Engine servicing

- Replacement of line replaceable units (LRU)

Main aspects of this level are:

- significant on-wing maintenance and troubleshooting

- easy access for routine maintenance

- Engine Maintenance \& Monitoring System (EMMS) or Engine Maintenance \& Tracking Systems (EMATS)

- fast line replaceable unit (LRU) replacement

- state of the art engine fault system identifies problems quickly to ensure operational safety

II. Intermediate (I) - Level, Base Engine Shop

Maintenance repair of engines and modules that cannot be repaired with engine installed in aircraft.

Main aspects of this level are:

- return to service by module replacement reduces engine down time

- simple and quick engine testing

- avionics shop and jet engine intermediate maintenance (JEIM) shop can maintain controls

- engine design maximizes base-level repair ability

- I-level maintenance arranged around horizontal repair and vertical (modular) maintenance.
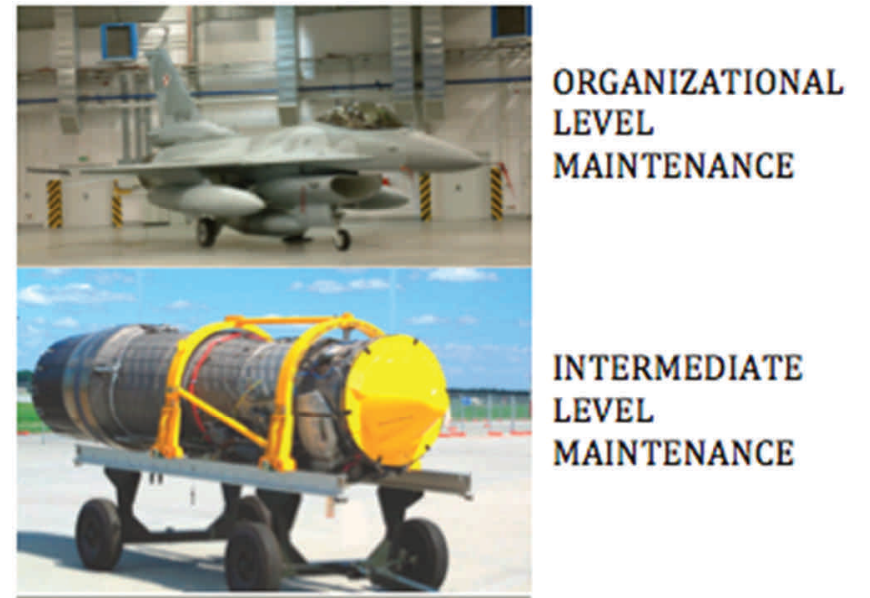

INTERMEDIATE

LEVEL

MAINTENANCE

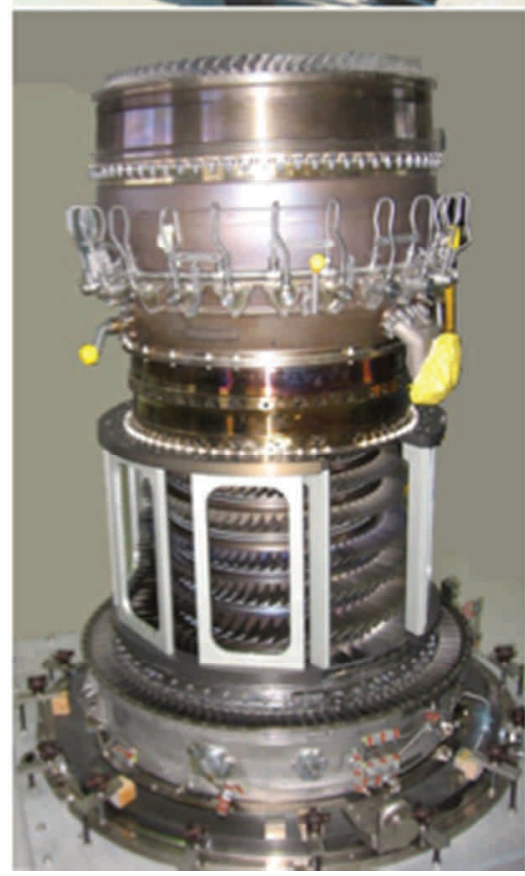

DEPOT

LEVEL

MAINTENANCE

Fig. 3. Levels of maintenance

This type of maintenance could be divided into two sections:

1. Horizontal engine discrepancies removal (Fig. 4)

2. Vertical engine/module repair (Fig. 5)

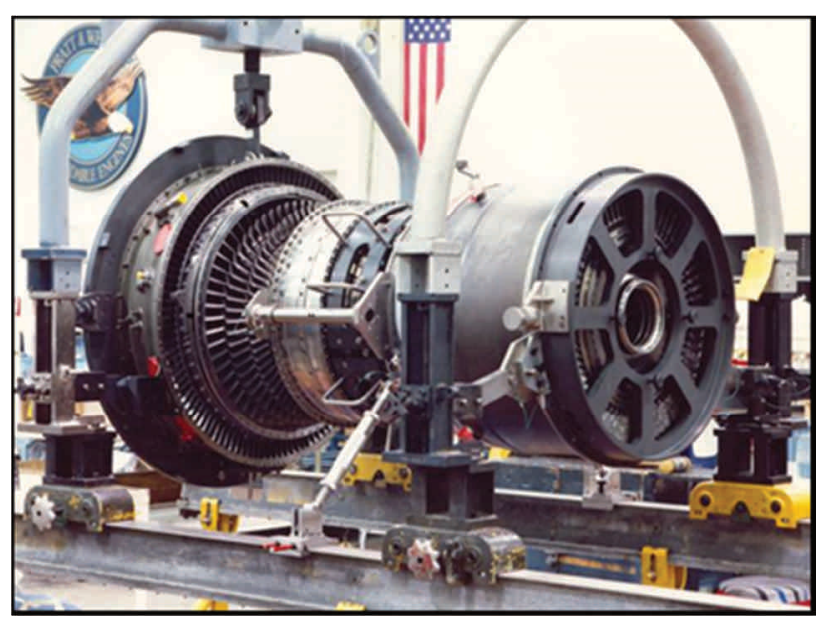

Fig. 4. Horizontal repair section 


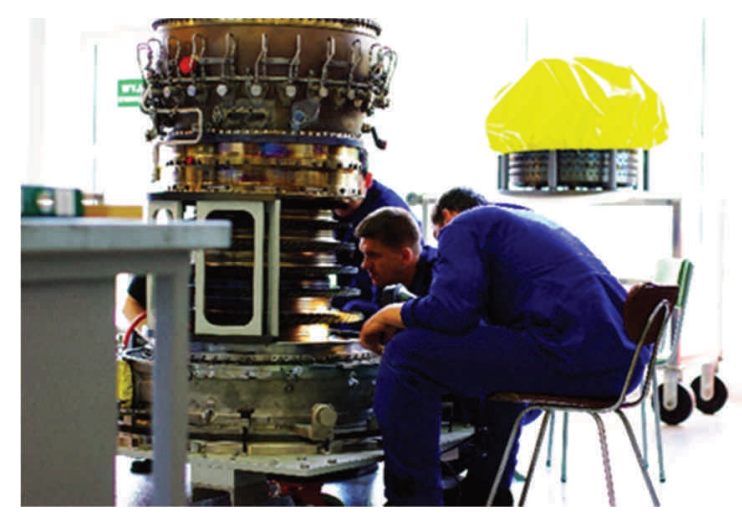

Fig. 5. Vertical repair section

III. Depot (D) - Level - Centralized Engine/Module Repair Repairs that cannot be made at either Organizational or Intermediate maintenance levels. Specialized tools are required for component and parts repair.

Main aspects of this level are:

- comprehensive engine/module repair and overhaul beyond capability at I-level

- customer controls fleet maintenance and depot/repair options based on:

- Flying/utilization trends

- Fleet size

- Annual budgets

- Utilizing established depot \& repair infrastructure

- Applying Material Management Program

- Leveraging in-country organic capabilities

\section{Hazard identification}

In order to identify hazards, hazard sources we should try to recognize what are the most common undesired events as far as the engine maintenance is concerned. The main events being tracked by all the international safety management personnel and engine manufacturers are:

1. F100 ENGINE RELATED LOSS OF AIRCRAFT (ERLOA)

2. NON-RECOVERABLE IN FLIGHT SHUTDOWN NRIFSD

3. IN FLIGHT SHUTDOWNS (IFSD)

Authors of this article researched F100-PW-229 engine maintenance system and analyzed this area of interest as a combination of three elements: human-hardwareenvironment. Considering all the relations between these elements we could identify single or multiple hazard sources. In this case the F100 engine maintenance system has been presented as an aggregated analysis domain model in order to implement procedures into the hazard identification process. This aggregated analysis domain is a combination of the three domains (Fig. 3), where hazards could be generated as a result of the maintenance processed performed at different levels of the F100 engine maintenance system.

For the study purposes, analysis domain 2 has been selected, representing second level of the engine maintenance system (engine intermediate level maintenance). One of the main maintenance processes performed at this level is major engine objects discrepancies removal. In this article this process is an area of the hazard identification. The selected process consists of the eleven following steps:

1. Engine receiving inspection

2. Pre-test cell engine mount

3. Engine/LRU preservation (engine run on TC)

4. Broken module removal (Gearbox, Augmentor, Fan, Core, LPT)

5. Modules/LRU inspections

6. Spare module installation

7. Engine Final assembly

8. Pre-test cell inspections

9. Pre-test cell engine mount

10. Test cell run

11. Engine Final Inspection

In this article, due to complexity of the F100 turbofan engine, authors considered only one process of the major engine object discrepancy removal. The main reason for the following research was that aircraft crew chief reported engine oil leakage during postflight inspection. After borescope inspection it was determined that this leakage is beyond acceptable limits.

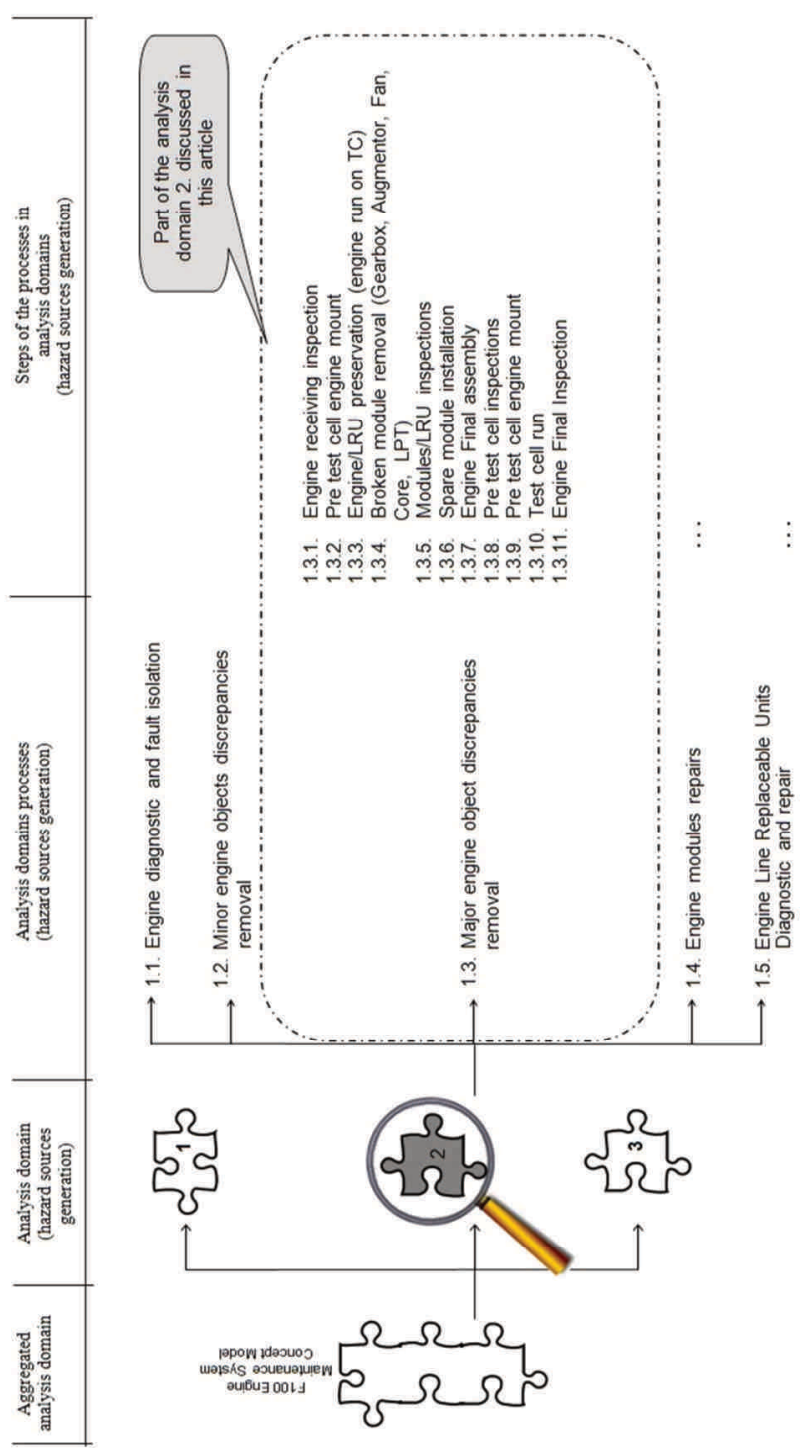

Fig. 6. Detailed schematic diagram of the aggregated analysis domain structure (detailed: Analysis domain 2. - Engine Intermediate level maintenance) being the model of the F100 engine maintenance system 
Hazard identification process in the selected analysis domain of the F100 turbofan engines maintenance system

\section{Hazard sources identification}

Hazard sources identification in the selected analysis domain is being conducted in accordance with the procedures of the forward hazard identification process. The list of the selected identified hazard sources within process 1.3 (major engine object discrepancies removal) is presented in Table 1.

Table 1. List of the selected identified hazard sources in the analysis domain (Engine Intermediate level maintenance) within process 1.3 (major engine objects discrepancies removal) - Fig. 3 and 6

\begin{tabular}{|c|c|}
\hline No. & Identified hazard sources \\
\hline$-1-$ & $-2-$ \\
\hline \multicolumn{2}{|r|}{$\begin{array}{l}\text { 1. HAZARD SOURCES LIST - STEP } 1 \text { OF THE PROCESS } 1.3 \\
\text { (Fig. 6) }\end{array}$} \\
\hline$<1.1>$ & $\begin{array}{l}\text { Engine technician performing receiving inspection neglects } \\
\text { other engine objects and does not identify other broken objects. }\end{array}$ \\
\hline$<1.2>$ & $\begin{array}{l}\text { Engine technician performing inspection leaves tool in the } \\
\text { engine nozzle. }\end{array}$ \\
\hline$<1.3>$ & $\begin{array}{l}\text { Engine technician performing receiving inspection does not } \\
\text { identify broken blades in the LPT (Low Pressure Turbine) }\end{array}$ \\
\hline$<1.4>$ & $\begin{array}{l}\text { Engine technician uses broken light source during borescope } \\
\text { inspection does not identify chaffing fuel tube in the combustion } \\
\text { chamber. }\end{array}$ \\
\hline$<1.5>$ & $\begin{array}{l}\text { Engine technician performs receiving inspection neglects chaff- } \\
\text { ing clamps on the fuel tubes. }\end{array}$ \\
\hline$<1.6>$ & $\begin{array}{l}\text { Engine technician using pliers accidentally cuts engine harness } \\
\text { and damages signal wire to DEEC. }\end{array}$ \\
\hline$<1.7>$ & $\begin{array}{l}\text { Engine technician uses outdated technical documentation with- } \\
\text { out new safety and crucial inspections }\end{array}$ \\
\hline $1.8>$ & $\begin{array}{l}\text { Engine technician using broken borescope is unable to identify } \\
\text { eroded turbine blades. }\end{array}$ \\
\hline & $\ldots$ \\
\hline \multicolumn{2}{|r|}{ 2. HAZARD SOURCES LIST - STEP 2 OF THE PROCESS 1.3 (Fig. 6) } \\
\hline$<2.1>$ & $\begin{array}{l}\text { Engine technicians improperly mount engine on the T4000 } \\
\text { trolley }\end{array}$ \\
\hline$<2.2>$ & $\begin{array}{l}\text { Engine technician do not perform any safety position papers on } \\
\text { engine }\end{array}$ \\
\hline$<2.3>$ & Engine technician leaves FOD inside engine \\
\hline$<2.4>$ & Engine technician does not torque fuel tube nut bolt \\
\hline . & $\cdots$ \\
\hline \multicolumn{2}{|r|}{ 3. HAZARD SOURCES LIST - STEP 3 OF THE PROCESS 1.3 (Fig. 6) } \\
\hline$<3.1>$ & Engine technician neglect unusual noise from HPT \\
\hline$<3.2>$ & Fire suppression system in the test cell is not working \\
\hline$<3.3>$ & Engine technician does not notice fuel leak \\
\hline$<3.4>$ & Engine technician does not notice oil leak \\
\hline$<3.5>$ & $\begin{array}{l}\text { Communication fail between test cell operator and engine tech- } \\
\text { nician }\end{array}$ \\
\hline & $\cdots$ \\
\hline \multicolumn{2}{|r|}{ 4. HAZARD SOURCES LIST - STEP 4 OF THE PROCESS 1.3 (Fig. 6) } \\
\hline$<4.1>$ & Engine technician uses broken crane to remove module \\
\hline$<4.2>$ & Engine technician is unable to operate crane \\
\hline$<4.3>$ & $\begin{array}{l}\text { Engine technician uses broken hydraulic wrench to disassembly } \\
\text { engine modules }\end{array}$ \\
\hline$<4.4>$ & $\begin{array}{l}\text { Engine technician does not use IETM documentation while } \\
\text { modules removing }\end{array}$ \\
\hline$<4.5>$ & $\begin{array}{l}\text { Engine technician unable to use technical documentation proper- } \\
\text { ly }\end{array}$ \\
\hline & \\
\hline
\end{tabular}

\begin{tabular}{|l|l|}
\hline 5. HAZARD SOURCES LIST - STEP 5 OF THE PROCESS 1.3 (Fig. 6) \\
\hline$<5.1>$ & Engine technician roughly inspects augmentor liner \\
\hline$<5.2>$ & Engine technician does not notice No3 bearing seal damaged \\
\hline$<5.3>$ & Engine technician leaves nuts on MFC not safety wired \\
\hline$<5.4>$ & Engine technician is unable to identify augmentor burn through \\
\hline$<5.5>$ & Engine technician does not notice cracked LPT blade \\
\hline$\ldots$ & $\ldots$ \\
\hline 6. HAZARD SOURCES LIST - STEP 6 OF THE PROCESS 1.3 (Fig. 6)
\end{tabular}

\section{Hazards specification}

Hazards specification process is conducted in accordance with the following procedures: hazards sources grouping and hazards formulation.

Hazard sources grouping. This process is based on the previously created list of the hazards sources (Table 1). Not every selected source of the hazard from the list and not every combination of the other hazard sources, generates analysis domain status, where the developed scenario could 
result into loss/harm (in this article - engine/aircraft damage, ERLOA, personnel injury, etc). The main goal of the hazard sources grouping procedure is creation of the groups of the hazard sources which could generate such an analysis domain status, where the developed scenario could result into the loos/harm. Results of this process are presented in Table 2 (segment "Hazard sources group H...").

Hazard formulation and predicted loss/harm during hazard activation. In order to formulate hazards, we select a group of the hazard sources which creates a certain analysis domain status might result into the loss/harm. Hazard formulation should express fear of the potential loss/harm (caused by undesired side effects) like for instance: NRIFSD, ENG Thrust Loss, Compressor STALL, Engine Exhaust Fire, FOD/DOD, Engine Throttle malfunction, etc.). Some proposed results of the hazard formulation procedure with the predicted loss caused by their activation are presented in Table 2, in the following segments: "Hazard formulation...", "Predicted loss/harm caused by hazard activation".

Table 2. Final results of the selected hazards specification process generated in analysis domain 2, within process 1.3 (major engine objects discrepancies removal) - own elaboration

\begin{tabular}{|c|c|}
\hline & Hazard H1 \\
\hline \multicolumn{2}{|c|}{ Hazard sources group H1 } \\
\hline 1. & $\begin{array}{l}\text { Engine technician uses broken light source during borescope } \\
\text { inspection does not identify chaffing fuel tube in the combus- } \\
\text { tion chamber. }<1.4>\end{array}$ \\
\hline & $\begin{array}{l}\text { Engine technician performs receiving inspection neglects chaff- } \\
\text { ing clamps on the fuel tubes. }<1.5>\end{array}$ \\
\hline 3. & Engine technician does not notice fuel leak. $<3.3>$ \\
\hline & $\begin{array}{l}\text { Engine technician performs engine final inspection roughly and } \\
\text { does not verify oil/fuel leaks. }<11.1>\end{array}$ \\
\hline 5. & Engine supervisor does not verify engine status $<11.2>$ \\
\hline \multicolumn{2}{|c|}{$\begin{array}{l}\text { Hazard formulation } \mathrm{H} 1 \\
\text { Hazard of loss resulting from fact, that engine fuel leak appears during } \\
\text { flight and was not identified during engine discrepancy removal. }\end{array}$} \\
\hline Predic & uring $\mathrm{H} 1 \mathrm{~h}$ \\
\hline
\end{tabular}

\section{Hazard $\mathbf{H 2}$}

Hazard sources group $\mathrm{H} 2$

1. Engine technician using broken borescope is unable to identify eroded turbine blades. $<1.8>$

2. Engine technician does not notice cracked LPT blade. $<5.5>$

3. Engine supervisor does not verify engine status

Hazard formulation $\mathrm{H} 2$

Hazard resulting from the fact that one of the Low Pressure Turbine blades cracks and tears off.

Predicted loss/harm during $\mathrm{H} 2$ hazard activation

Loss resulting from the turbine damage.

\section{Hazard H3}

Hazard sources group H3

1. Engine technician does not notice oil leak. $<3.4>$

2. Engine technician does not torque nuts on oil tubes. $<7.2>$

3 . Engine technician performs engine final inspection roughly and does not verify oil leaks $<11.1>$

4. Engine quality assurance verify paper work only without engine verification. $<11.3>$

Hazard formulation $\mathrm{H} 3$

Hazard of loss resulting from the fact that engine oil leak appears during flight and engine bearings lubrication system failure .

Predicted loss/harm during $\mathrm{H} 3$ hazard activation

Loss resulting from the fact, that engine seizures up.

\section{Hazard H4}

Hazard sources group H4

1. Engine technician performs receiving inspection neglects chaffing clamps on the fuel tubes. $<1.5>$

2. Engine technician uses broken light source during borescope inspection does not identify chaffing fuel tube in the combustion chamber. $<1.4>$

3. Engine technician does not notice fuel leak. $<3.3>$

4. Engine technician performs engine final inspection roughly and does not verify oil/fuel leaks. $<11.1>$

5. Engine supervisor does not verify engine status $<11.2>$

6. Engine quality assurance verify paper work only without engine verification. $<11.3\rangle$

Hazard formulation $\mathrm{H} 4$

Hazard of loss resulting from the fact that fuel leaks and does not reach combustion chamber.

Predicted loss/harm during H4 hazard activation Loss resulting from the NRIFSD

\section{Hazard H5}

\section{Hazard sources group H5}

1. Engine technician does not verify engine thrust pins and instal old and cracked ones. $<9.2>$

2. Engine technician does not respect/follow safety rules during engine run. $<10.3>$

\section{Hazard formulation $\mathrm{H} 5$}

Hazard of loss resulting from the fact, that engine thrust pins were not inspected by engine technician and were cracked.

Predicted loss/harm during H5 hazard activation

Loss resulting from the facts, that during engine high power tests in the test cell, engine liberated from the trolley and was severely damaged

\section{Hazard H6}

Hazard sources group H6

1. Engine technician performing receiving inspection neglects other engine objects and does not identify other broken objects $<1.1>$

2. Engine supervisor does not verify proper engine final assembly. $<7.5>$

3. Engine operator does not verify engine performance parameters while engine test run. $<10.1>$

4. Engine supervisor does not verify engine status. $<11.2>$

5. Engine quality assurance verify paper work only without engine verification. $\langle 11.3\rangle$

Hazard formulation $\mathrm{H} 6$

Hazard of loss resulting from the fact, that engine throttle malfunction was not identified.

Predicted loss/harm during H6 hazard activation

Loss resulting from the engine throttle malfunction and ERLOA

\section{Summary}

Pratt\&Whithey engine F100-PW-229 powering polish F-16Block $52+$ is a very modern and advanced engine. However, due to its high power and very low intake, it is very vulnerable to the so-called FOD Foreign Object Damage. Engine and engine components repairs and overhauls on base level is the unprecedented situation in the Polish Air Forces. Military technicians responsible for this task must be aware of the hazards concerned with the engine maintenance processes. In this article authors selected intermediate level maintenance as an analysis domain and identified hazards generating such an analysis domain, which could result into the loss or harm. The main goal of this article was to show maintenance management personnel main hazards sources within engine maintenance processes. Elimination of these hazards sources directly affects F-16 safety system. 


\section{Nomenclature}

DEEC digital engine electronic controller

LRU line replaceable unit

ERLOA engine related loss of aircraft

TCTO time compliance technical order

EMMS engine maintenance \& monitoring system

EMATS engine maintenance \& tracking systems

HPT high pressure turbine

TC engine test cell

IETM interactive engine electronic technical manual
MFC main fuel controller

FOD foreign object damage

DOD domestic object damage

LPT low pressure turbine

NRIFSD non-recoverable in flight shutdown

PEER periodic engineering excellence review

MAP maintenance awareness program

\section{Bibliography}

[1] LOCKHEED MARTIN STM 16-329PL (Poland Block 52) F100-PW-229 POWER PLANT.

[2] Biuletyn Eksploatacyjny, 2006, praca zbiorowa, $\mathrm{Nr}$ P/O/R/U/4901/E/2006, dotyczy: eksploatacji samolotu F16.

[3] F100-PW-229 Periodic Engineering Excellence Reviev.

Sławomir Szrama, MEng. - Squadron Commander at $31^{\text {st }}$ Air Force Base Poznań-Krzesiny.

e-mail:S.Szrama@ron.mil.pl
[4] KADZIŃSKI, A. Studium wybranych aspektów niezawodności systemów oraz obiektów pojazdów szynowych. Wyd. Politechniki Poznańskiej, seria Rozprawy. 2013, 511.

[5] Szczegółowe zasady funkcjonowania służby inżynieryjnolotniczej w JW1156.

[6] Technical Manual T.0.00-20-1 Aerospace Equipment Maintenance Inspections, Documentation, Policies and procedures.

Adam Kadziński, DSc., DEng. - Faculty of Mechanical and Transport Engineering at University of Technology.

e-mail: Adam.Kadzinski@put.poznan.pl 